特 別

講 演

\section{本邦非金属鉱業の最近の動向*}

Recent Trend of Industrial Minerals and Rocks in Japan

\title{
Kenji TOMITA
}

\section{1. まえがき}

非金属鉱物はその種類が多く, あるあのは重要産業の 基礎原材料として, また，あるあのは国民生活に密着し た日用品等の原材料として利用されている。乙れらの非 金属鉣物の多くは国内資源によってまかなわれ，乙れま で需要の増大に応じて国内生産す増大の一途をたどり, 我が国の産業之国民生活の発展向上に寄与してきた。

しかしながら, 資源開発の発展にとあなう開発地域の 奥地化，都市化に伴なう合理的な資源開発の制約，環境 保全その他の権益との調整の困難性, 労㗢力不足, など の諸問題が顕在化しつつあり, 中小・零細企業が多い非 金属鉱業によって，今後も増大する需要に対応した供給 の確保, あるいは需要の減退に対応した安定供給の確保 を期するてとは次第に困難となってきている。

今後, 非金属鉱物資源の安定供給と非金属鉱業の健全 な発展を期するためには，乙れらの問題点の実態を的確 に把握しておかなければなら好が, 前述のように中小・ 零細企業が多く，かつ全国的な業界団体をむたない鉱種 が多いため, その実態が十分に把握されていない傾向が 強い。従って, 本稿でも本邦非金属鉱業の最近の動向を 述べるという所期の目的を達成するてとは極めて困難で あるが，以下，関係者の御協力をえて，その一端にふれ てみたいと思う。

\section{2. 最近10年間の動き}

非金属鈗物生産量の最近10年間の動きをみると，いく つかの傾向がみられる。その 1 つは需要の増大に対応し た国内生産量の増加および輸入量の増加である。第 2 は, 低品質の釷石の利用と新しい原料の利用である。第 3 は 技術革新あるいは経済情勢の変動によって需要に著しい 変動が生じている鉱種があるというととである。第 1 表 はこの10年間の需給関係の変化を示すむのとして, 非金

* 昭和53年11月 7 日本会第61回例会において発表

** 工業技術院公害資源研究所次長

昭和53年10月 5 日受理
属鉱物の生産量を昭和 41 年之昭和 51 年で比較したもので ある。この表は昭和 41 年から 51 年までの 10 年間に, 次の ような動向がみられたてとを示している。

(1) 生産量が減少したあの

石高, ダイアスポア, 木節粘土, 頁岩粘土, 石綿, 長石, 風化花崗岩, 硫黄

（2） $1 \sim 2$ 倍に生産量が増加したもの

ろう石, ろう石クレー, 半花崗岩, 陶石, カオリ ン, 滑石, 重晶石, 炉材珪石, 天然珪砂, 人造珪砂, 蛙目珪砂

（3） 2 倍以上飞生産量が増加したもの

蛙目粘土, 白珪石, 軟珪石, 石灰石, ドロマイト この10年間に生産量が減少したもののうち, 天然硫黄 は公㲅方止のため原油から抽出回収された回収硫黄の増 加によって圧迫されたすので, 元素硫黄を産出する日本 の硫黄鉱山は昭和 48 年 3 月で全部休止している。今後, いつの日か, 我が国で消費する石油のすべてが, 産油地 で精製される時がくるまで，国内の硫黄鉱床の再開は困 難であろう。また, 天然石育の生産は副産物である化学 石膏の増大によって需要增を吸収され，ついに10年前の 生産量の10\%にまで抑制されてしまった。ダイアスポア の減少は鉱床の涸枯にも原因がある。

この10年間の経済成長からみると，1～2 倍にしか生 産量が増加しなかった非金属鉱物は, 生産が鈍化したも のと考えられるものである。陶石，カオリン，ろう石な どは良質の鉱石の涸枯, 採掘の困難性の増大などのため に生産があまり伸びていない。重晶石は黒鉱選鉱の副産 物として産出する割合が多く, その生産量は黒鉱生産量 に左右される。天然珪砂, 人造珪砂, 蛙目珪砂について はいずれも, 板ガラス, 瓶ガラス, 鋳物砂の需要増に伴 なってかつては著しく生産量が増大してきたが, 最近は 輸入珪砂量む少しづつ増加しており，顕著な伸びがみら れない。

生産量がての 10 年間に 2 倍以上に増加したものは, 一 応経済成長に見合った生産増をとげた非金属鉱物と考え 
穊1表非金属鉱物生産量比較 ${ }^{2)}$

(単位: $t$ )

\begin{tabular}{|c|c|c|c|c|c|c|c|c|c|c|c|c|}
\hline 鉱 & 種 & $\begin{array}{c}\text { 昭和 } 41 \text { 年 } \\
(\mathrm{A})\end{array}$ & $\begin{array}{c}\text { 昭和 } 51 \text { 年 } \\
\text { (B ) }\end{array}$ & B / A & & 鉱 & & 種 & & $\begin{array}{c}\text { 昭和 } 41 \text { 年 } \\
\text { (A) }\end{array}$ & $\begin{array}{l}\text { 昭和51年 } \\
\text { (B) }\end{array}$ & $\mathrm{B} / \mathrm{A}$ \\
\hline 石 & 骨（精鉱量） & 597,651 & 64,831 & 0.11 & 滑 & & 石（精 & 鉱量 & & 104,708 & 104,836 & 1.00 \\
\hline ろ & 石 (" " ) & $1,004,268$ & $1,240,407$ & 1.24 & 重 & 晶 & 石 ( & " & ) & 40,274 & 53,704 & 1.33 \\
\hline ろう石クレ & $--(\|)$ & 364,946 & 451,698 & 1.24 & 硫 & & 黄 ( & " & ) & 229,714 & - & - \\
\hline ダイアスオ & ゚゚ア (" I) & 4,907 & 1,909 & 0.39 & 白 & 珪 & 石 ( & " & ) & 622,061 & $1,660,701$ & 2.67 \\
\hline 木 節 粘 & 土（粗鉱量） & 457,165 & 435,813 & 0.95 & 軟 & 珪 & 石 ( & " & ) & $2,208,769$ & $6,944,154$ & 3.14 \\
\hline 頁岩粘 & 土 $(" \|)$ & 447,514 & 213,464 & 0.48 & 炉 & 材 珪 & 石 ( & " & ) & 280,922 & 324,081 & 1.15 \\
\hline 半花 崗 & 岩（精鉱量） & 292,332 & 357,915 & 1.22 & 天 & 然珪 & 砂 ( & $"$ & ) & $1,659,496$ & $3,055,878$ & 1.84 \\
\hline 風化花崗 & 岩 (") & 7,700 & - & - & 人 & 造珪 & 砂 ( & " & ) & 492,827 & 708,765 & 1.44 \\
\hline 陶 & 石 (" ") & 249,468 & 251,118 & 1.01 & 蛙 & 目 珪 & 砂 ( & " & ) & 436,537 & 474,524 & 1.09 \\
\hline カオリ & ン $(" 1)$ & 117,563 & 226,073 & 1.92 & 石 & 灰 & 石 ( & " & ) & $71,449,856$ & $147,530,444$ & 2.06 \\
\hline 蛙 目 粘 & 土( $(1)$ & 298,158 & 594,864 & 2.00 & ド & ㄱ 1 & $r($ & " & ) & $1,711,238$ & $5,523,653$ & 3.23 \\
\hline 石 & 綿 (" I) & 19,439 & 7,703 & 0.40 & 長 & & 石 ( & " & ) & 51,661 & 41,217 & 0.80 \\
\hline
\end{tabular}

られる。乙れらのなかには, この10年間に生産量は增加 したが, 品質的には低品質のものがより多く利用され, それによって量的に増加したあのあある。軟珪石はセメ ント用の珪酸質岩石で, セメントの増産に比例して生産 が増加している。石灰石むセメント生産の增大に比例し て増加したあのである。白珪石は本来, ガラス製品, 製 鋼用に用いられるが, 最近は土木用の需要が増加してい る。ドロマイトについても, 農業用, 土建用としての需 要が順調に増大している。

\section{3. おもな非金属釷業の概況}

\section{1 石灰 石}

石灰石はそのまま建築材として用いられるほか，セメ ント，鉄鋼等の基幹産業の工業用原料を中心として広い 用途がある。わが国における石灰石の需要は，てれらの 産業の発展に支えられて増大してきた。昭和52年の石灰 石生産量は 1 億 5,451 万 $\mathrm{t}$ で前年より $4.7 \%$ 増であり, 用 途別出荷量で最もウエイトの高いのはセメント用で, 総 出荷量に占める割合は $56.6 \%$ ついで土建用 $15.8 \%$, 鉄鋼 用 $15.7 \%$, 石灭用 $6 \%$ の順となる。セメント用は 52 年の セメント生産が前年比 $6.4 \%$ 増之順調に増加したてとあ あって $6 \%$ 增となったが, 鉄鋼用は $7.3 \%$ 減, 石灰用は 横ばいである。乙れらに対し, ソーダ・ガラス用, 炭力 ル・石粉用，土建用，その他はいずれあ増加となった。 カーバイト用は，かつて鉄鋼用に次ぐ需要先であったが， カーバイト工業が石油化学工業によってとってかわられ た結果, カーバイト用石灰石の需要は激減した。炭力 ル・石粉用石灰石は従来の肥料用, 道路用のほか, ゴム 充填用, 塗料用, 増量用等の工業用の増加に加えて, 脱 硫剂之しても大量に用いられるなど, 今後その需要は拡 大してゆくあのと考元れている。
石灰石は需要のすべてが国内生産によってまかなわれ ている数少ない資源の一つであるが，てれまではての資 源の豊富な存在と採掘の大型化, 機械化によって, 増大 する需要に対し順調に供給がなされてきた。しかしなが ら, 石灰石の採掘は大部分が露天掘で, かつその規模が 大きいため, 自然環境及び緑地の保全等に関し, 相当な 配慮をしなければ, 従来のように需要の増大に応じた安 定供給を行うことは困難になってきている。

\section{2 ドロマイト}

ドロマイトは製鋼用等の炉材として多く用いられるほ か, 苦土肥料, ガラス, プラスター, 土建用等にあ利用 される。昭和 52 年における生産量は 575 万 $\mathrm{t}$ で前年より $4.1 \%$ 増であり，用途別にウエイトの高いものは鉄鋼用 で50.5\%を占め, 前年比 $20.7 \%$ 増, 次いで土建用は 20.3 \%で12.3\%減, 炭カル用は11.8\%で17.8\%増, ガラス用 は5.3\%で3.8\%減となっている。

鉄鋼用のドロマイトは今迄主として平炉, 電気炉等の 耐火材として用いられてきたが，その比率は年々低下し てきている。てれは製鋼の主体がドロマイト使用量の多 い平炉鋼からドロマイト使用量の少ない転炉鋼に急速に 転換したためである。

\section{3 珪石}

珪石は光学ガラス, フェロシリコン, 研削材, セメン 卜, 耐火煉瓦, 陶磁器, 電子機器等の原料として用いら れる。昭和51年の白珪石, 軟珪石, 炉材珪石を含めた出 荷量は 884 万 $\mathrm{t}$ であるが, このうち土建・その他用を除

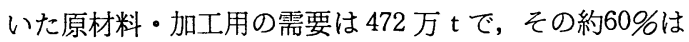
セメント用， $30 \%$ が鉄鋼・製鍊用である。セメント用と しては粉碎が容易な軟珪石が用いられており，その需要 の伸びは珪石全体の伸びとほぼ同じ推移をたどってい る。土建用に供されるむのは, 品質上他の用途化使用す 
るととが困難な軟珪石の一部で, 埋立用等一般の土砂と ほほ同様に取扱われており，その実用実績は必らずしも 明らかでない。

セメント用，鉄銁用，耐火煉瓦用，土建用等の珪石は すへて国内鉱山から供給されているが, 光学用, 金属シ リコン, 研削材用等の純度の高い製品用に用いられる珪 石は主として韓国，中国，北朝鮮，インドなどから輸入 され，とくに金属シリコン用はほとんど全量を韓国から 輸入している。

\section{4 珪 砂}

わが国における珪砂の需要は年々漸増し, 昭和51年の

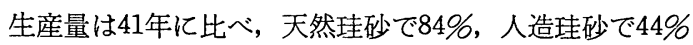
蛙目珪砂で10\%増となり, 昭和52年の珪砂生産量は 432 万 5 千 $\mathrm{t}$ 亿達した。珪砂のおむな用途は板ガラス, ガラ ス製品，鋳物砂などであるが，てのうち板ガラス用珪砂 の需要は年間 115 万 $\mathrm{t}$ 程度で, 現在のとてろ品質及び鉱 量ともに問題はない。長期的視点から豪州産のものが若 干量輸入されている。ガラス製品用の珪砂は瓶ガラスの 主原料として調合原料の70\%を占めるほか, 管球ガラス の製造にも必要な原料で, 需要の伸び率は他の用途のも のに比べて大きくなっている。上記の板ガラス, ガラス 製品に，需要の約30\%を占める鋳物砂を加えた 3 部門で 全需要量の $90 \%$ 近くを占めるが, てれらのほかに, 珪酸 ソーダ, ガラス繊維等の需要部門の拡大に伴なって, 珪 砂の需要量は着実に増大してゆくあのと考えられる。

てれまで, これらの珪砂の需要に対する供給は大部分 が国内生産によってまかなわれてきているが, 輸入も徐 々に増大し, 昭和51年には国内天然珪砂生産量の $13.5 \%$ に相当する41万 $\mathrm{t}$ が主としてオーストラリアから輸入さ れている。

わが国の珪砂生産量の約70\%を産する瀬戸地域, 多治 見地域等の東海地方は都市化の進展が著しく, 珪砂が賦 存する公有地が宅地等の用途のために開放される例が多 く, 地下資源の合理的な開発が困難となってきつつある ほか, 採掘跡地の整備む大きな問題となってきている。 珪砂原土を水洗して精製する際に生ずる微粒の廃棄物 （通称「キラ」）は原土の約20\%に達し, その対策が重要 な問題となってきている。

\section{5 耐火祜土}

耐火粘土の昭和 51 年の需要量の比率は陶磁器用 $32 \%$, 耐火煉瓦用38\%で，乙の両者で約70\%を占める。従って 耐火粘土の需要の動向はこれら耐火煉瓦, 陶磁器業界の 動向に大きく左右される。耐火煉瓦は鉄鋼部門の消費が 圧倒的に大きく, 原料耐火粘土の需要も鉄鋼生産, とく に高炉関係の建設需要の多少に影響されるとてろが大き い。なお, 陶磁器用耐火粘土については, 乙て数年来, 需要は横ばいで推移している。
耐火粘土の埋蔵鉱量は昭和 48 年 4 月現在で 1 億 $\mathrm{t}$ 亿及 んでいるが，次第に品質の低下を来たし，ささらに鉣物賦 存地域の都市化, 環境問題などと相まって, 資源的にみ てあ，また採掘条件などからみても；将来楽観を許さぬ 現状である。また, 高アルミナ質, 塩基性, その他特殊 耐火物の発達, プラスチックス, キャスタブルその他不 定型耐火物の開発などによって粘土質煉瓦は, 最近やや 停滞現象を呈している。

また, 一方では, 最近の耐火物生産の高度化, 多角化 に伴ない，攀土頁岩をはじめ各種の粘土質原料が主とし て, 韓国, アメリカ, 南アフリカ等から輸入されており, たしかに耐火粘土業界では構造的な変革が進行中である ととが窺われる。

\section{6 万う石}

ろう石はろう石質耐火煉瓦，とくに取鍋用煉瓦の原料 として用いられるため, その需要は鉄鋼生産の動向に左 右される。しかし，煉瓦業界における省力化の一環とし て，サンドクレンザー工法の普及によって原料ろう石の 使用量は従来のように鉄鋼生産に平行して伸長するとは 考えられないようになってきている。

ろう石はタイルの原料としても用いられるが, 一般建 設業界の影響に極めて鋭敏に反応するので，常に需要業 界の動向を予測する必要に迫られている。

上記の窯業用のほか，乃う石はクレ一原料として大量 に使用されるが，そのうち一般印刷紙フィラー用は将来 とも固定した需要が期待されるが, 上質紙, アート紙の コート用については，摩耗度の点で他の鉱物質原料（滑 石，カオリンなど）に較べて問題があり，高品位鉱の確 保が重要な課題になっている。長期的な需給構造につい て考えると, クレーと輸入カオリン，滑石等との競合問 題が今後の最大の課題となろう。

\section{4. おもな非金属鉱物の輸入状況}

わが国で生産されている空業製品のうち多くの製品は, 一般的に高品質の窯業製品に求められる良質の原料鉱物 が我が国にそしいため，その原料供給を輸入に依存して いるのが現状である。輸入原料がわが国の窯業に占める 位置は, 量の面からみれば，国産原料，合成人工原料， 翰入原料の比率が $3: 1: 1$ となっており, また金額の 面からみれば, $2: 5: 3$ となっている。てれは高級原 料が輸入されていることを示し，また合成人工原料のう ち, 合成ムライト, 電融アルミナ, 焼成アルミナなどは それぞれ輸入天然原料を使用するので, 輸入原料の占め る位置は一そう大きい6)。

わが国の需要をほとんど輸入でまかなっているものに, 製紙用カオリン（米国ジョージア州），高アルミナ質耐 火粘土 (中国攀土頁岩), 黒鉊 (ソ連), 石綿 (カナダ), 
蛍石（タイ）, 重晶石 (中国), ボーキサイト（オースト ラリアより金属アルミ用), クロム鉄鉱（南アフリカよ り金属クロム用, フィリピンより耐火物用), ジルコン (オーストラリア), 硼素（トルコ）, マグネサイト（朝 鮮)などがある。乙れらのうち，大部分の産地はそれぞ れ世界の主要産地であって，それらの我が国の不足非金 属鉱物資源の依存度の高さと，地球上の非金属資源の偏 在性と，それへの需要依存という様相を示している99。

第 2 表に昭和 52 年におけるおすな非金属鉱物の輸入状 況を示す。

\section{5. 昭和51年の非金属鉣業概況}

昭和51年の我が国鉱工業生産活動は, 鉱工業生産指数 で前年比 $13.3 \%$ 増と 3 年振りに上昇した。これは昭和 48 年の石油ショックを契機として, 鉱工業生産は加つな い大幅な落ち込みを記録したが，その深刻な不況む，昭 和 50 年 $1 \sim 3$ 月期を底にして回復に向い，昭和51年に入 って, 年初には輸出の急増, 耐久消費材を中心とした個 人消費の一時的な盛り上り等から, 生産がかなり急速な 回復を示したととによる。しかしながら，年央から年後

第2表打むな非金属鉱物輸入状洗*（昭和52年）

\begin{tabular}{|c|c|c|c|c|}
\hline 鉱種 & 輸 $\left(\begin{array}{c}\text { 量 } \\
(t)\end{array}\right.$ & 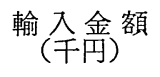 & 主 要 輸 入 国 & その他の輸入国 \\
\hline 珪 砂 & 433,228 & $2,118,529$ & $\begin{array}{l}\text { オーストラリヤ (89\%), 韓国 (6\%), } \\
\text { サラワク (4\%) }\end{array}$ & $\begin{array}{l}\text { 中国, フィリピン, クエート, フラン } \\
\text { ス, 西ドイッ, イタリヤ, カナダ, 米 } \\
\text { 国 }\end{array}$ \\
\hline $\begin{array}{l}\text { 石英及び } \\
\text { 珪岩 }\end{array}$ & 171,493 & $1,921,466$ & $\begin{array}{l}\text { 韓国 (65\%), タイ(14\%), インド } \\
(7 \%) \text {, 中国 }(6 \%)\end{array}$ & $\begin{array}{l}\text { 北鮮, 台湾, マラヤ, フィリピン, ス } \\
\text { ウェーデン, 西ドイツ, ソ連, 米国, } \\
\text { ブラジル, アンゴラ, マダガスカル, } \\
\text { オーストラリヤ }\end{array}$ \\
\hline カオリン & 404,320 & $12,772,900$ & $\begin{array}{l}\text { 米国 (73\%), 韓国 (22\%), 北鮮 } \\
(2 \%)\end{array}$ & $\begin{array}{l}\text { 香港, シンガポール, マラヤ, インド } \\
\text { ネシア, インド, 英国, 西ドイツ, ス } \\
\text { ペイン, ブラジル, タンザニア, オー } \\
\text { ストラリア, ニュージーランド }\end{array}$ \\
\hline $\begin{array}{l}\text { その他の } \\
\text { 粘土 }\end{array}$ & 170,000 & $4,176,278$ & $\begin{array}{l}\text { 米国 (48\%), 南アフリカ }(25 \%) \text {, 北 } \\
\text { 鮮 }(21 \%)\end{array}$ & $\begin{array}{l}\text { 中国, 台湾, フィリピン, インド, } \\
\text { ラク, 英国, 西ドイツ, ガテマラ, エ } \\
\text { ジプト, 南阿, オーストラリア, = } \\
\text {-ジーランド }\end{array}$ \\
\hline $\begin{array}{l}\text { カイアナ } \\
\text { イト、ア } \\
\text { ンダルサ } \\
\text { イト, } \\
\text { か }\end{array}$ & 22,432 & 930,273 & $\begin{array}{l}\text { 南アフリカ }(67 \%), \text { 米国 (16\%), イ } \\
\text { ンド }(14 \%)\end{array}$ & 中国, オーストラリア \\
\hline $\begin{array}{l}\text { ムライト, } \\
\text { シャモッ } \\
\text { ト, ほか }\end{array}$ & 48,768 & $1,040,565$ & 韓国 (65\%), 米国 (35\%) & ベルギー, フランス, 西ドイッ \\
\hline 石綿 & 300,636 & $30,502,529$ & $\begin{array}{l}\text { カナダ }(40 \%), \text { 南アフリカ }(27 \%), \\
\text { ソ連 }(24 \%)\end{array}$ & $\begin{array}{l}\text { 韓国, 中国, インド, 英国, イタリヤ, } \\
\text { サイプラス, 米国, スイス, オースト } \\
\text { ラリヤ }\end{array}$ \\
\hline タルク & 326,945 & $5,521,126$ & $\begin{array}{l}\text { 中国 }(54 \%), \text { 韓国 (17\%), オースト } \\
\text { ラリア }(16 \%)\end{array}$ & 北鮮, インド, イタリア, 米国 \\
\hline $\begin{array}{l}\text { 長石, 泉 } \\
\text { 稫石 } \\
\text { 石閃長 }\end{array}$ & 12,335 & 171,956 & $\begin{array}{l}\text { 中国 (47\%), 北鮮 (24\%), 韓国 } \\
\text { (19\%) }\end{array}$ & インド, カナダ, 米国 \\
\hline
\end{tabular}

* セラミックス, 第 13 巻第 5 号 p. 430 (昭和 53 年 5 月) 
第 3 表非金属鉱業関係釷区出願件数推移 1 )

\begin{tabular}{|c|c|c|c|c|c|c|c|c|c|}
\hline 年 & & 度 & 45 & 46 & 47 & 48 & 49 & 50 & 51 \\
\hline 試 & 掘 & 願 & 1,674 & 1,424 & 1,325 & 1,786 & 1,300 & 757 & 682 \\
\hline 採 & 掘 & 願 & 405 & 336 & 326 & 1,064 & 313 & 161 & 150 \\
\hline
\end{tabular}

第 4 表 非金属鉱業関係鉱区数及び鈗区面 皘1)（昭和51年）

(単位:アール)

\begin{tabular}{|c|c|c|c|c|c|c|c|c|c|c|c|c|c|c|}
\hline \multicolumn{2}{|c|}{ 通 産 局 } & 国 & 幌 & 仙 & 京 & 名古屋 & 大 & 阪 & 広 & 島 & 四 & 国 & 福 & 岡 \\
\hline 試 & 数 & 1,136 & 80 & 159 & 62 & 339 & & 111 & & 136 & & 72 & & 177 \\
\hline 掘 & 面 皘 & $22,150,550$ & $1,627,174$ & $3,629,698$ & $1,202,203$ & $7,231,220$ & 2,483 & 391 & 2,161 , & 964 & & 14,557 & 2,870 & 343 \\
\hline 採 & 数 & 3,726 & 111 & 466 & 491 & 805 & & 250 & & 610 & & 334 & & 659 \\
\hline 掘 & 面 皘 & $39,946,025$ & $1,680,997$ & $5,275,206$ & $6,055,220$ & $7,170,490$ & 3,498 & 426 & 6,050 , & 862 & 3,51 & 3,323 & 6,701 &, 501 \\
\hline
\end{tabular}

第 5 表非金属鉱物関係埋蔵量 ${ }^{1)}$

\begin{tabular}{|c|c|c|c|c|c|c|c|c|c|c|}
\hline \multirow[b]{2}{*}{ 種 } & \multirow{2}{*}{$\begin{array}{l}\text { 調 査 } \\
\text { 年月日 }\end{array}$} & \multicolumn{3}{|c|}{ 埋 蔵 鉱 量 } & \multicolumn{3}{|c|}{ 可 採 粗 鉱 量 } & \multirow{2}{*}{ 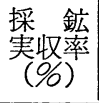 } & \multirow{2}{*}{$\begin{array}{c}\text { ズ 步 } \\
\text { 混入率 }\end{array}$} & \multirow{2}{*}{ 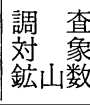 } \\
\hline & & 鉱 $\left(10^{3} t\right)^{\text {量 }}$ & $\begin{array}{l}\text { 品位 } \\
(\%)\end{array}$ & $\begin{array}{l}\text { 贪有 量 } \\
\left(10^{3} t\right)\end{array}$ & $\left(10^{3} t\right)^{\text {鋰 }}$ & $\begin{array}{l}\text { 嵒位 } \\
(\%)\end{array}$ & $\begin{array}{l}\text { 含有量 } \\
\left(10^{3} \mathrm{t}\right)\end{array}$ & & & \\
\hline ドロマイト & 44.4 .1 & 989,770 & 17 & - & 546,819 & 17 & - & 55.4 & 4.9 & 46 \\
\hline 耐 火 粘 土* & "I & 176,606 & - & - & 116,658 & - & - & 66.1 & 12.8 & 127 \\
\hline 蛙 目 粘 土 & " & 49,045 & - & - & 42,657 & - & - & 87.0 & 1.3 & 61 \\
\hline 石 灰 石 & "I & $40,663,039$ & 54 & - & $26,565,966$ & 54 & - & 65.3 & 1.3 & 333 \\
\hline 白 珪 & 46.4 .1 & 722,674 & 95.8 & 692,376 & 497,549 & 93.7 & 466,015 & 59 & 5 & 71 \\
\hline 天然珪 砂 & "I & 358,635 & 83.3 & 298,573 & 248,681 & 75.3 & 187,265 & 63 & 8 & 67 \\
\hline 育 & 50.4 .1 & 17,374 & 30.8 & 5,359 & 5,354 & 28.1 & 1,505 & 28 & 10 & 6 \\
\hline 重 晶 石 & " & 8,146 & 23.9 & 1,948 & 6,316 & 28.4 & 1,480 & 74 & 4 & 5 \\
\hline 炉 材 珪 石 & " & 168,984 & - & - & 105,017 & - & - & 57 & 8 & 14 \\
\hline 蛙 目 珪 砂 & " & 34,571 & 47.2 & 16,429 & 28,841 & 47.4 & 13,681 & 83 & 0 & 57 \\
\hline 石 & " & 179,381 & - & - & 151,753 & - & - & 43 & 26 & 78 \\
\hline
\end{tabular}

* 頁岩粘土, 木節粘土

半にかけて個人消費が再び低迷し, 輸出も伸びが鈍化し たてとから, 生産は年末にかけて停滞気配を強め, 本格 的な景気の立直りを見ないままに終った。

鉱業は対前年比では数年来減少の傾向を示していたが, 昭和 51 年において生産は $0.4 \%$, 出荷は $1.1 \%$ とわずかな がら上昇となった。てれは非金属鉱業の生産 $5.8 \%$, 出 荷 $6.9 \%$ 上昇によるあのであり，てれ以外の鉱業では 低下, 若しくは横ばいの状態を示している。在庫は $4.9 \%$ の低下となった。

昭和51年の非金属鉱物は，生産，出荷がそれぞれ $5.8 \%$, 6.9\%の上昇を示し, 在庫む5.9\%の上昇であった。主要 鉱種の生産を前年に比べてみると, ドロマイト $27.6 \%$ 増, ろう石 $15.6 \%$ 増, 珪砂 $8.2 \%$ 増, 万う石クレー2.9\%増,

第 6 表 非金属釷業関係従業者数 ${ }^{1)}$ (昭和 51 年末）

\begin{tabular}{|c|c|c|c|c|c|}
\hline \multirow{2}{*}{ 鉱 } & \multirow{2}{*}{$\begin{array}{l}\text { 事業 } \\
\text { 所数 }\end{array}$} & \multicolumn{2}{|c|}{ 常用従業者数 } & \multirow{2}{*}{$\begin{array}{l}\text { 臨時従 } \\
\text { 業者数 }\end{array}$} & \multirow{2}{*}{$\begin{array}{l}\text { 請負従 } \\
\text { 業者数 }\end{array}$} \\
\hline & & $\begin{array}{l}\text { 生 産 } \\
\text { 部 }\end{array}$ & $\begin{array}{l}\text { 管 理 } \\
\text { 部 閒 }\end{array}$ & & \\
\hline 耐 火粘土 & 48 & 282 & 88 & 16 & 60 \\
\hline ろう石 & 84 & 1,357 & 459 & 17 & 79 \\
\hline ドロマイト & 25 & 829 & 216 & 9 & 298 \\
\hline 石 & 28 & 165 & 41 & 7 & 7 \\
\hline 石 & 33 & 533 & 105 & 33 & 20 \\
\hline カオリン & 19 & 249 & 60 & 7 & 59 \\
\hline 蛙目粘土 & 47 & 412 & 102 & - & 80 \\
\hline 石 & 90 & 936 & 277 & 31 & 142 \\
\hline 天然珪砂 & 100 & 1,258 & 503 & 55 & 68 \\
\hline 石 灰 石 & 259 & 5,011 & 1,788 & 152 & 5,250 \\
\hline 滑 & 14 & 83 & 13 & 1 & 11 \\
\hline
\end{tabular}

Vol. 25, No. 4 ('78冬) 
第7表 非金属鉱業関係総 合選鈗能力1)(昭和51年)

\begin{tabular}{|c|c|c|c|c|c|c|c|c|c|c|c|c|c|c|c|c|c|c|}
\hline \multirow{3}{*}{ 鉱 種 石 } & \multicolumn{4}{|r|}{ 工 } & 程 & 別 & 処 & 理 & 能 & & 力 & & & & \multirow{2}{*}{\multicolumn{2}{|c|}{ 選鉱 総合能力 }} & \multirow{2}{*}{\multicolumn{2}{|c|}{ 年間処理奏績 }} \\
\hline & \multirow{2}{*}{$\begin{array}{l}\text { 手 } \\
t / \text { 月 }\end{array}$} & & \multicolumn{2}{|l|}{ 破 } & \multirow{2}{*}{$\frac{\text { 磨 }}{t / \text { 月 }}$} & \multirow{2}{*}{$\begin{array}{l}\text { 転 } \\
\text { 工場 } \\
\text { 数 }\end{array}$} & \multicolumn{2}{|c|}{ 比重選 鉱 } & \multicolumn{2}{|c|}{ 磁力選 鉱 } & \multicolumn{2}{|c|}{ 浮遊選鉱 } & \multirow{2}{*}{$\begin{array}{l}\text { 焼 } \\
\mathrm{t} / \text { 月 }\end{array}$} & \multirow{2}{*}{$\begin{array}{l}\text { 鉣 } \\
\text { 工場 } \\
\text { 数 }\end{array}$} & & & & \\
\hline & & $\left|\begin{array}{|c|}\text { 場 } \\
\text { 数 }\end{array}\right|$ & $t /$ 月 & $\begin{array}{c}\text { 工場 } \\
\text { 数 }\end{array}$ & & & $t /$ 月 & $\begin{array}{c}\text { 工場 } \\
\text { 数 }\end{array}$ & $t /$ 月 & $\begin{array}{c}\text { 工場 } \\
\text { 数 }\end{array}$ & $\mathrm{t} /$ 月 & $\mid$\begin{tabular}{|c|c|} 
工場 \\
数
\end{tabular} & & & $\mathrm{t} /$ 月 & $\left|\begin{array}{|c|}\text { 場 } \\
\text { 数 }\end{array}\right|$ & $\mathrm{t} /$ 年 & $\mid$\begin{tabular}{|} 
工場 \\
数
\end{tabular} \\
\hline ろう石 & 51,570 & 38 & 71,275 & 29 & 24,415 & 12 & 12,820 & 7 & $x$ & 1 & 34,910 & 9 & $x$ & 1 & 141,120 & 57 & 992,878 & 5 \\
\hline ドロマイト & $x$ & 2 & 883,576 & 15 & $x$ & 1 & - & - & - & - & - & - & $x$ & 1 & 881,856 & 15 & $7,197,052$ & 16 \\
\hline 石 & 14,737 & 12 & 16,050 & 9 & - & - & - & - & - & - & $x$ & 2 & - & - & 31,147 & 17 & 286,951 & 17 \\
\hline 石 & 7,200 & 11 & $x$ & 2 & - & - & - & - & - & - & - & - & - & - & 6,750 & 6 & 88,939 & 9 \\
\hline カオリン & 2,700 & 4 & $x$ & 1 & $x$ & 2 & $x$ & 2 & - & - & 5,100 & 3 & - & - & 25,300 & 5 & 85,190 & 5 \\
\hline け い 石 & 23,635 & 13 & 515,300 & 32 & 60,300 & 5 & - & - & - & - & $x$ & 1 & - & - & $1,041,775$ & 32 & $3,382,467$ & 34 \\
\hline 天然けい砂 & & 2 & 31,200 & 5 & 56,008 & 8 & $x$ & 2 & $x$ & 2 & 20,100 & 4 & - & - & 83,508 & 13 & 844,450 & 13 \\
\hline 石 灰 & 172,704 & 16 & $14,173,305$ & 146 & 20,144 & 6 & $x$ & 2 & 一 & - & $x$ & 1 & $x$ & 1 & $24,777,170$ & 136 & $106,988,528$ & 141 \\
\hline
\end{tabular}

第 8 表非金属鉱業関係鉱害保安設 備 ${ }^{1)}($ 昭和51年)

\begin{tabular}{|c|c|c|c|c|c|c|c|c|c|c|c|c|c|c|c|}
\hline \multirow{3}{*}{ 業 } & \multirow{3}{*}{ 種 } & \multirow{3}{*}{ 名 } & \multirow{3}{*}{ 事業所数 } & \multicolumn{8}{|c|}{ 坑 - 廃 水 処 理 施 設 $\left(\mathrm{m}^{3} /\right.$ 月 $)$} & \multicolumn{4}{|c|}{ 捨石・沈澱物堆皘場 $\left(\mathrm{m}^{3}\right)$} \\
\hline & & & & \multicolumn{2}{|c|}{ 中 } & \multicolumn{2}{|c|}{ 反 } & \multicolumn{2}{|c|}{ 沈 澱 - 分 離 } & \multicolumn{2}{|l|}{ 沪 } & \multicolumn{2}{|l|}{ 捨 } & \multirow{2}{*}{$\frac{\text { 沈 }}{\text { 数 }}$} & 港 物 \\
\hline & & & & 数 & 処理能力 & 数 & 処理能力 & 数 & 処理能力 & 数 & 処理能力 & 数 & 処理能力 & & 処理能力 \\
\hline 耐 & 火 粘 & 土 & 26 & & & & & 42 & 24,890 & 2 & 3,840 & 34 & 156,630 & 5 & 7,300 \\
\hline ろ & う & 石 & 49 & 47 & 900,249 & 15 & 181,360 & 59 & 393,043 & 25 & 119,092 & 42 & $1,602,950$ & 39 & 57,373 \\
\hline ド & ロマイ & ト & 18 & - & - & - & - & 8 & 366,350 & 1 & 3,360 & 13 & 89,658 & 5 & 55,210 \\
\hline 長 & & 石 & 12 & - & - & - & - & 15 & 6,183 & - & - & 7 & 50,170 & 4 & 30,110 \\
\hline 陶 & & 石 & 21 & 3 & 4,600 & 2 & 4,570 & 15 & $2,032,150$ & 8 & 46,190 & 25 & $1,611,060$ & 41 & 33,900 \\
\hline 力 & オリ & ン & 8 & 7 & 439,200 & 1 & 15,000 & 2 & 18,000 & 3 & 87,000 & 8 & 444,328 & 1 & 200 \\
\hline 蛙 & 目 粘 & 土 & 24 & 1 & 500 & - & - & 37 & 201,705 & 16 & 154,370 & 9 & $1,147,900$ & 10 & 36,600 \\
\hline 珪 & & 石 & 44 & 3 & 68,573 & 1 & 24,000 & 51 & 211,494 & 21 & 19,336 & 18 & 33,375 & 25 & 34,025 \\
\hline 天 & 然 珪 & 砂 & 66 & 8 & 280,713 & 1 & 18,000 & 81 & $1,115,714$ & 100 & 37,001 & 19 & $1,750,822$ & 44 & 639,790 \\
\hline 石 & $\tau$ & う & 1 & - & - & - & - & - & - & - & - & - & - & - & - \\
\hline 石 & 灰 & 石 & 96 & 3 & 4,100 & 1 & 3,000 & 122 & 990,005 & 22 & 47,327 & 120 & $30,202,645$ & 55 & $2,685,502$ \\
\hline 滑 & & 石 & 3 & - & - & - & - & 9 & 7,930 & - & - & 5 & 17,800 & - & - \\
\hline
\end{tabular}




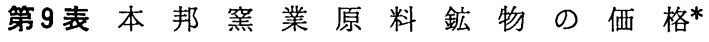

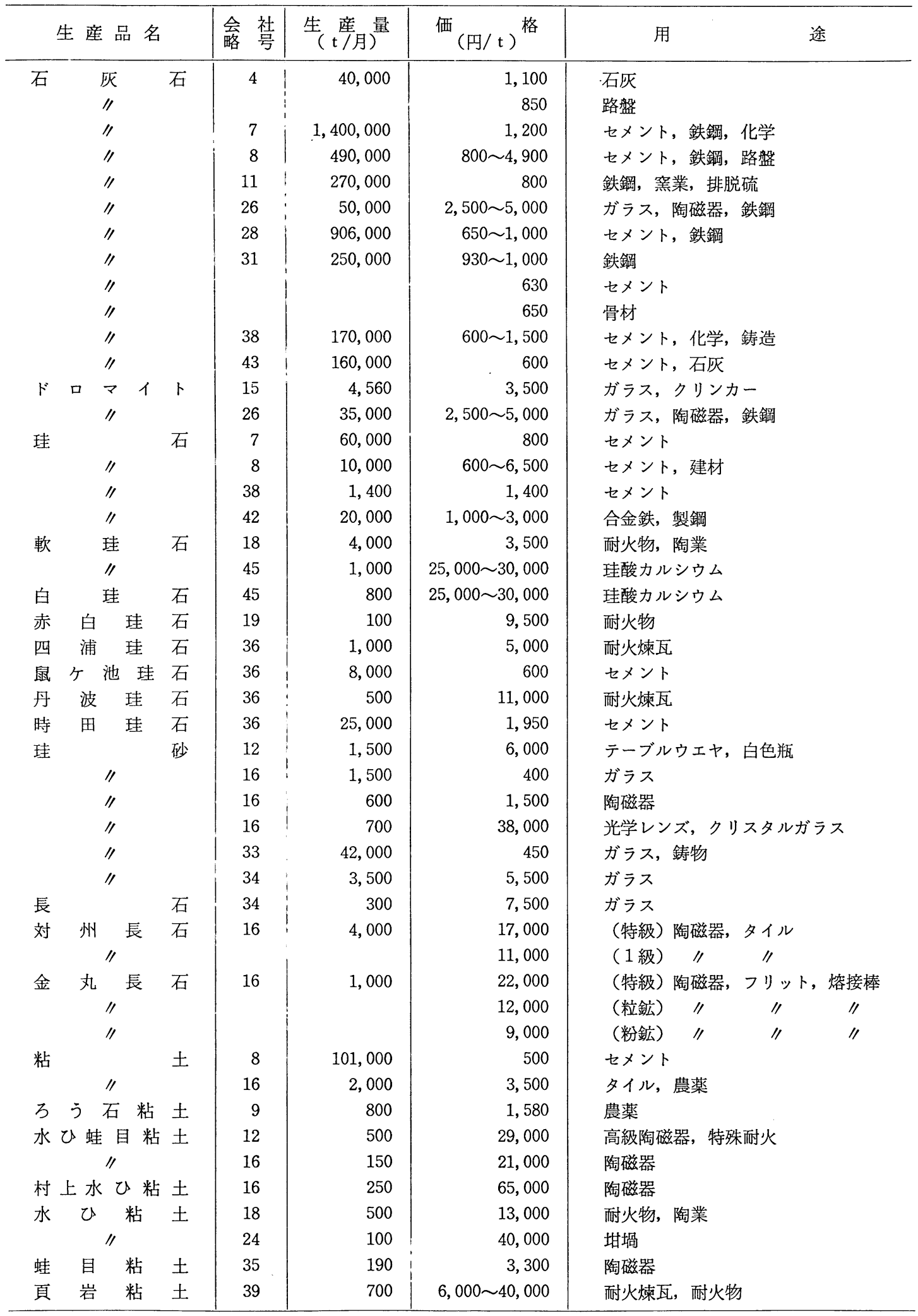


（第 9 表つづき）

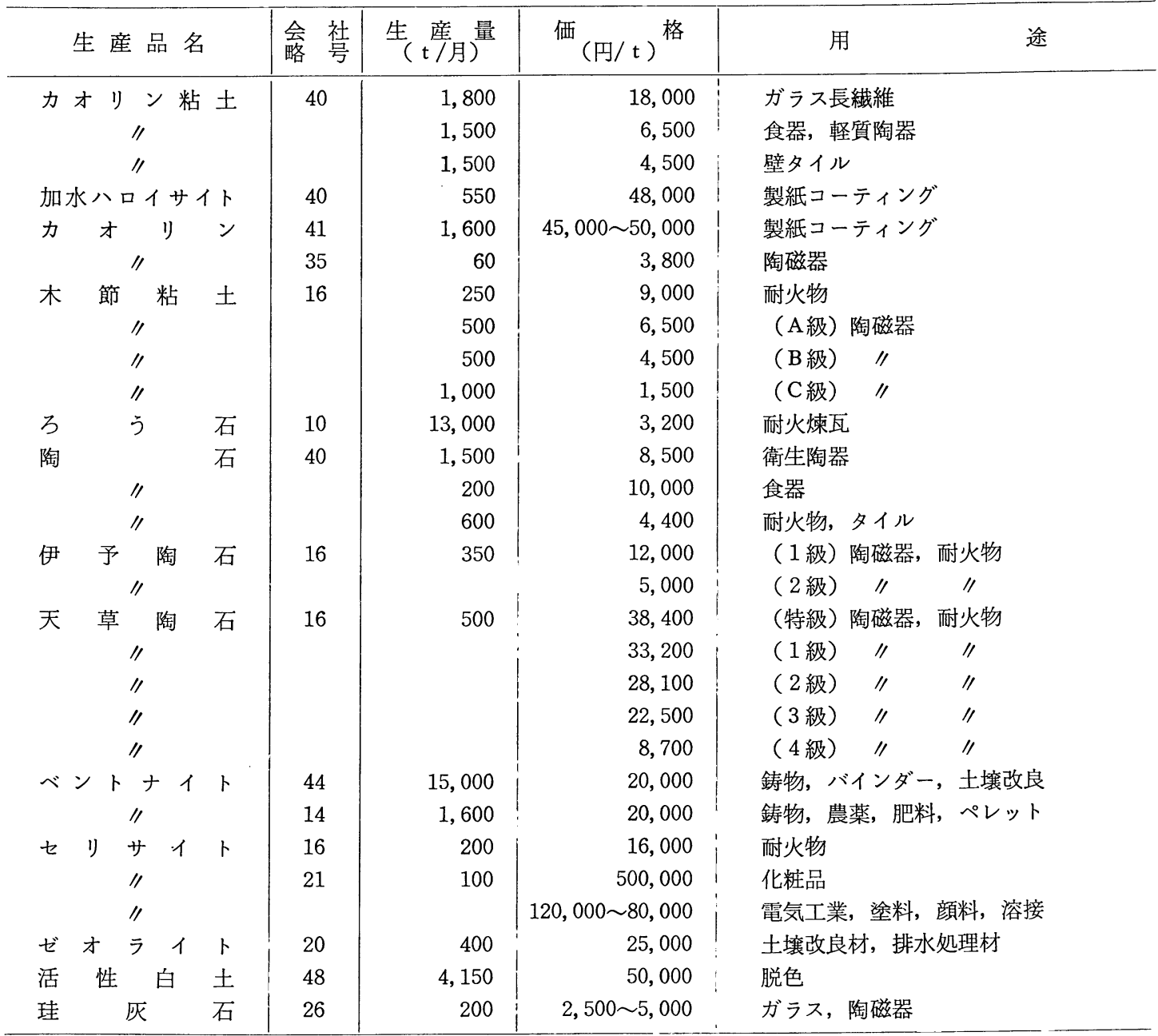

* 空業協会原料部会編「日本の割業原料一1977」(昭和53年 3 月)

石灰石 $2.6 \%$ 増, 珪石1.9\%増とそれぞれ増加したが, 石 㠇は65.3\%の大幅な減少となった。

昭和 51 年における非金属鉱業の概況として，第 3 表に 釷区出願件数の推移，第 4 表に鉱区数と釷区面積，第 5 表に埋蔵鉱量, 第 6 表に従業者数, 第 7 表に総合選鈗能 力，第 8 表に鉱害保安設備をそれぞれ示す。また第 9 表 には本邦産窯業原料鉱物の価格を示す。

\section{6. むす び}

非金属鉱業は我が国の各種産業に密着した基盤産業で あり, 過去, それぞれの業界の動向に対応して，好況時 には増産態勢を, 不況時には操業短縮の対応を余儀なく されてきた。一方, 経済の低成長化は世界的な規模で広 がり, 我が国は輸出超過からドル減らしを迫られ, 年初 からは急激な円高で攻められている。これらの影響は当
然非金属鉱業にあ及んでくる。

例えば，低成長下における我が国の中・長期粗鋼生産 の見通しについては、不透明であるが，海外諸国では製 鉄所の建設が進み, 自給化する傾向にあるので, 輸出比 率の高い我が国鉄鋼業の輸出は徐々に低下せざるをえな いむのと考えられる。乙のような趨勢から，我が国の粗 鋼生産は中期的な見通しとしては現状の横ばいの程度, 長期的な見通しとしては減少してゆくあのと考えられて いる。従って, 今後, より一層, 国際化が進展してゆく なかで，基幹産業の盛衰に直接関係のある非金属鉱業の うちのある種の業界にとっては，いかにして国際競争力 を確保してゆくかが最大の課題となっている。

一例として, 耐火物原料について述べると, 年々輸入 原料と人工合成原料の比率が増加してゆく傾向がある。 このため，天然原料を含めた国内原料メ一カーの国家的 
保護育成と輸入原料供給国との交流，情報交換，並びに 輸入供給源の多角化等の必要性が提唱されており, 今後 は世界的な視野に立った経済的な原料の確保が要請され ている。

一方，我が国の非金属資源は石灰石をはじめ，特殊な あのを除いては金属資源に較べると，需要に対する埋蔵 資源量の割合は大きい。しかし国内的には立地難や環境 保全対策などの問題が多く，国内資源の新規開発はなか なか困難である。現在の原料消費量からみれば，次第に 自給率は低下してゆくことになる。

てれらの諸問題に対処するためには，各方面に亘る研 究と技術開発に負うとてろが大きく，とくに選鉱技術の 進展が果す役割は大きく，その成果が期待されている。

謝辞

本稿をまとめるにあたっては，通商産業省資源エネル ギー庁鉱業課の担当官からは貴重な資料の御提供をいた
だき，また工業技術院地質調查所鉱床部長岡野武雄氏か らは多くの御教示を賜わった。下記の引用文献の著者の 方々ととあ，特に記して厚く御礼を申し上げる。

\section{引用 文 献}

1）通商産業省：本邦鉱業の趨勢，昭和51年

2）通商産業省：資源統計年報，昭和51年

3）窵業界の展望（昭和 52 年度），七ラミックス，第 13 巻第 9 号, 昭和 53 年 9 月

4）空業協会原料部会：日本の案業原料一1977, 昭和53 年 3 月

5）岡野武雄：非金属釷業原料最近の動向（その 1 , そ の 2 ), 地学雑誌, 第83巻第 6 号及び第 84 巻第 5 号, 昭和 49 年及び昭和 50 年

6）岡野武雄, 藤井紀之: 輸入窯業原料の現状, セラミ ックス, 第 11 巻第 2 号, 昭和 51 年 2 月

8）岡野武雄：世界の鉱産における最近の動向, 地理, 昭和 51 年 5 月

9）岩生周一：非金属鉱物資源，日本の鉱物資源（共立 出版）昭和 52 年 4 月 